\title{
KARAKTERISTIK DAN MUTU BERAS LOKAL KABUPATEN BULUNGAN KALIMANTAN UTARA
}

\author{
(Characteristics And Quality Of Local Rice In Bulungan District, North Kalimantan)
}

\author{
Fitrah Pangerang $^{1 *}$, Nila Rusyanti ${ }^{2)}$ \\ 1*) Jurusan Agroteknologi Pertanian Universitas Kaltara, Indonesia \\ *) email Penulis Korespondensi: fitrah_pangerang @yahoo.com
}

\begin{abstract}
ABSTRAK
Mutu beras sangat menentukan harga beras dan selera konsumen. Penelitian ini bertujuan untuk mengidentifikasi karakteristik dan mutu beras lokal berdasarkan standar SNI 01-61282015. Penelitian ini dilakukan dengan metode eksplorasi. Jumlah beras yang diambil adalah 1 kg. Setiap beras lokal diamati sifat fisik dan mutunya. Sifat fisik meliputi derajat putih, kebeningan, bentuk dan ukuran beras sedangkan mutu beras disesuaikan dengan mutu standar SNI 01-6128-2015. Hasil menunjukkan bahwa sifat fisik beras lokal memiliki derajat putih yang bervariasi antara 58,8 - 54,6\%. Dimana jenis beras krayan dan beras keladi menunjukkan derajat putih tertinggi. Nilai kebeningan beras lokal menunjukkan di kisaran $1.70-2.57 \%$. Tingkat kebeningan beras mempengaruhi tingkat kesukaan konsumen. Ukuran beras lokal memiliki kategori berukuran panjang dan sedang. Beras yang berukuran panjang adalah beras Puy, Ikang, Angga dan beras Merah yang dibudidayakan dengan sistem pertanian sawah tradisional di dataran rendah dengan ukuran panjang (6,5-7) mm. Sedangkan beras yang berukuran sedang adalah jenis beras krayan dan beras keladi yang dibudidayakan secara organik dengan sistem pertanian sawah tradisional oleh masyarakat dataran tinggi dengan ukuran panjang $(5,5-5,6) \mathrm{mm}$. Bentuk beras lokal memiliki bentuk beras ramping $(2,8-3,5)$ dan bentuk beras medium (2,2-2,8). Beras Ikang, Angga dan krayan memiliki bentuk yang ramping sementara Puih, Keladi dan Merah memiliki bentuk medium. Ditinjau dari persyaratan mutu beras dari standar SNI (2015), terlihat bahwa beras lokal yang ada di Bulungan memenuhi persyaratan standar mutu beras III, IV dan V. Beras Ikang dan Krayan memenuhi mutu III. Beras Puy, Angga, dan Keladi memenuhi mutu beras IV. Sedangkan beras merah memenuhi mutu beras $\mathrm{V}$. Hal ini menujukkan bahwa beras lokal bulungan pasti perlu dilakukan penanganan pascapanen yang lebih baik untuk meningkatkan mutu beras sehingga beras yang dihasilkan mampu untuk bersaing dalam pasar. Kesimpulan beras lokal Bulungan memiliki karakteristik dengan ukuran dan bentuk beras ramping dan medium dengan mutu yang masih tergolong rendah.
\end{abstract}

Kata Kunci : Karakteristik, Beras Lokal, mutu, sifat fisik

\section{ABSTRACT}

The quality of rice determines rice prices and consumer tastes. This study aims to identify the characteristics and quality of local rice based on SNI 01-6128-2015 standards. This research was conducted by exploration method. The amount of rice taken is $1 \mathrm{~kg}$. Each local rice is observed for its physical properties and quality. Physical properties include white degree, clarity, shape and size of rice while the quality of rice is adjusted to the standard quality SNI 01-6128-2015. The results show that the physical properties of local rice have white degrees which vary between 58.8 - 54.6\%. Where the type of krayan rice and rice taro shows the highest white degree. The value of clarity of local rice shows in the range of $1.70-2.57 \%$. The level of rice clarity affects the level of consumer preference. The size of local rice has a long and medium sized category. Long-term rice is Puy, Ikang, Angga and Red rice which are cultivated with traditional lowland rice farming systems with a length (6.5-7) $\mathrm{mm}$. While 
medium-sized rice is the type of krayan rice and taro rice which are cultivated organically with traditional rice farming systems by the people of the highlands with a length (5.5-5.6) $\mathrm{mm}$. The form of local rice has the form of lean rice (2.8-3.5) and the form of medium rice (2.2-2.8). Ikang rice, Angga and krayan have a slim shape while Puih, Keladi and Merah have medium forms. Judging from the rice quality requirements of the SNI standard (2015), it can be seen that the local rice in Bulungan meets the requirements for quality standards for rice III, IV and $V$. Ikang and Krayan rice meets III quality. Puy, Angga and Keladi rice meets the quality of rice $I V$. While brown rice fulfills the quality of rice $V$. This shows that the local rice in Bulungan definitely needs better postharvest handling to improve the quality of rice so that the rice produced is able to compete in the market. Conclusion Bulungan local rice has characteristics with the size and shape of lean and medium rice with a relatively low quality.

Keywords : Characteristics, Local Rice, quality, physical properties

\section{PENDAHULUAN}

Kabupaten Bulungan Provinsi Kalimantan Utara merupakan wilayah di Indonesia yang terletak dibagian utara pulau kalimantan dengan kekayaan alam hayati yang melimpah, memiliki berbagai spesies tanaman lokal/khas yang hanya terdapat di provinsi ini. Diantara spesies tanaman tersebut adalah terdapatnya beberapa varietas tanaman padi lokal dengan sifatsifat unggulan yang tidak terdapat pada varietas-varietas lain.

Keragaman beras lokal Kabupaten Bulungan Kalimantan Utara, ini merupakan modal dasar yang sangat berharga untuk pengembangan pertanian sektor tanaman pangan dalam mendukung program swasembada pangan nasional dan keberadaannya hanya bisa bergantung kepada budidaya yang dilakukan oleh masyarakat setempat. Beras lokal merupakan plasma nutfah yang potensial dikembangkan sebagai sumber gen-gen yang mengendalikan sifat-sifat penting pada tanaman padi. Keragaman genetik yang tinggi pada padi-padi lokal dapat dimanfaatkan dalam program pemuliaan padi secara umum. Identifikasi sifat-sifat penting yang terdapat pada beras padi-padi lokal yaitu beras Krayan, beras Angga, beras Puy, beras keladi, beras merah dan beras ikang. perlu terus dilakukan agar dapat diketahui potensinya dalam program pemuliaan.
Beras lokal Kabupaten Bulungan memiliki sifat unggulan, yang diantaranya adalah kualitas rasa yang tinggi dan tahan terhadap cekaman lingkungan abiotik seperti kekeringan dan salinitas, aromanya yang wangi, bentuk beras kecil ramping yang disukai oleh petani dan konsumen serta pemeliharaan tanaman padinya sederhana. Keanekaragaman beras padi lokal di daerah ini belum banyak diketahui karakteristik dan mutu berasnya.

\section{METODOLOGI PENELITIAN}

\subsection{Prosedur Penelitian}

Penelitian dilakukan dalam dua tahap, tahap pertama dilakukan eksplorasi beras lokal untuk mendapatkan sampel beras. Pengambilan sampel dilakukan secara sengaja. Setiap jenis beras yang didapat diambil sebanyak $1 \mathrm{~kg}$. Tahap kedua dilakukan identifikasi karakteristik sifat fisik dan mutu beras lokal. Sifat fisik yang diamati meliputi derajat putih, nilai kebeningan dan ukuran dan bentuk beras lokal. Identifikasi mutu beras lokal berdasarkan standar mutu beras SNI 016128-2015 meliputi kadar air, butir patah, butir menir, butir mengapur, butir rusak/kuning, butir gabah dan butir benda asing. 


\section{HASIL DAN PEMBAHASAN}

\subsection{Sifat Fisik Beras}

Hasil pengujian indentifikasi karakteristik sifat fisik padi lokal beberapa daerah Bulungan disajikan pada Tabel 1.

Tabel 1. Hasil Identifikasi Karaktersitik Sifat fisik beras padi lokal di beberapa daerah Kabupaten Bulungan.

\begin{tabular}{ccccccccc}
\hline No & Varietas & $\begin{array}{c}\text { Derajat } \\
\text { Putih } \\
(\%)\end{array}$ & $\begin{array}{c}\text { Kebeningan } \\
(\%)\end{array}$ & $\begin{array}{c}\text { Panjang } \\
(\mathrm{mm})\end{array}$ & $\begin{array}{c}\text { Lebar } \\
(\mathrm{mm})\end{array}$ & $\begin{array}{c}\text { Rasio } \\
\text { P/L }\end{array}$ & $\begin{array}{c}\text { Ukuran } \\
\text { Beras }\end{array}$ & $\begin{array}{c}\text { Bentuk } \\
\text { Beras }\end{array}$ \\
\hline 1 & Puy & 54,0 & 2,57 & 6,5 & 2,5 & 2,6 & Panjang & Medium \\
2 & Ikang & 54,3 & 2,52 & 7 & 2 & 3,5 & Panjang & Ramping \\
3 & Angga & 54,5 & 2,52 & 7 & 2 & 3,5 & Panjang & Ramping \\
4 & Krayan & 57,6 & 1,55 & 5,6 & 2 & 2,8 & Sedang & Ramping \\
5 & Keladi & 58,8 & 1,70 & 5,5 & 2,5 & 2,2 & Sedang & Medium \\
6 & Merah & - & - & 7 & 2,5 & 2,8 & Panjang & Medium \\
\hline
\end{tabular}

Data Primer : Identifikasi Karakteristik Sifat Fisik Beras Lokal Bulungan

Hasil identifikasi karaktersitik sifat fisik beras padi lokal di beberapa daerah Kabupaten Bulungan menunjukkan bahwa derajat putih dari beberapa beras lokal yang ada di Bulungan bervariasi antara 58,8 $54,0 \%$. Dimana jenis beras Krayan dan beras Keladi menunjukkan derajat putih yang tinggi. Tingkat derajat putih diukur dari banyaknya lapisan dedak/bekatul dan lapisan silver skin yang terlepas dari butiran beras. Tingkat derajat putih menurut Bergman et.al (2006), dipengaruhi oleh kekerasan, ukuran dan bentuk, kedalaman lekukan butiran beras dan ketebalan lapisan bekatul. Sementara menurut (Setyono dan Wibowo, 2008), karakter ukuran dan bentuk beras dipengaruhi oleh faktor genetik, agroekosistem dan kesuburan tanah. Beras krayan dan beras keladi merupakan varietas lokal yang dibudidayakakan secara organik dengan sistem pertanian sawah tradisional oleh masyarakat dataran tinggi. Disamping itu nilai derajat putih berbanding lurus dengan derajat sosoh beras. Semakin tinggi nilai derajat putih, makin tinggi nilai derajat sosohnya (Lamberts et.al, 2007).

Karakteristik mutu fisik beras terhadap tingkat kebeningan beras mempengaruhi tingkat kesukaan konsumen. Pada umumnya konsumen menyukai beras yang bening dan mengkilat. Nilai Karakteristik mutu fisik beras terhadap tingkat kebeningan beras mempengaruhi tingkat kesukaan konsumen. Pada umumnya konsumen menyukai beras yang bening dan mengkilat. Nilai kebeningan varietas beras lokal menunjukkan di kisaran $1.70-2.57 \%$.

Ukuran dan bentuk beras merupakan karakter dominan yang diturunkan dari sifat genetik induk padinya. Ukuran beras lokal Bulungan memiliki kategori berukuran panjang dan sedang. Beras yang berukuran panjang adalah beras Puy, Ikang, Angga dan beras Merah dimana jenis beras ini umumnya dibudidayakan dengan sistem pertanian sawah tradisional di dataran rendah dengan ukuran panjang (6,5-7 ) $\mathrm{mm}$. Sedangkan beras yang berukuran sedang adalah jenis beras krayan dan beras keladi yang umumnya dibudidayakan secara organik dengan sistem pertanian sawah tradisional oleh masyarakat dataran tinggi dengan ukuran panjang $(5,5-5,6) \mathrm{mm}$. Sementara bentuk beras yang menunjukkan perbandingan antara panjang dan lebar beras utuh (rasio P/L) berdasarkan hasil pengamatan beras lokal memiliki bentuk beras yang bervariasi yaitu bentuk beras ramping $(2,8-3,5)$ dan memiliki bentuk beras medium (2,2-2,8). Beras Ikang, Angga dan krayan memiliki bentuk yang ramping sementara Puih, Keladi dan Merah memiliki 
bentuk medium. Menurut Setyono dan Wibowo (2008) bahwa ukuran dan bentuk beras dipengaruhi oleh sifat genetik, agroekosistem, dan kesuburan lahan.

\subsection{Standar Mutu Beras Lokal}

Mutu merupakan bagian penting untuk mampu bersaing dalam pasar produk pangan.
Untuk menghasilkan produk akhir yang baik, mutu harus dikendalikan diseluruh rantai pangan. Oleh karena itu mutu beras merupakan salah satu faktor yang menentukan tingkat penerimaan konsumen terhadap suatu varietas. Berdasarkan mutu giling beras lokal Bulungan menurut SNI 6128: 2015 disajikan pada Tabel 2.

Tabel 2. Komponen dan Penggolongan Mutu Beras Padi Lokal Kabupaten Bulungan

\begin{tabular}{cccccccccc}
\hline No & Varietas & $\begin{array}{c}\text { KA } \\
(\%)\end{array}$ & $\begin{array}{c}\text { Butir } \\
\text { Patah } \\
(\%)\end{array}$ & $\begin{array}{c}\text { Butir } \\
\text { Menir } \\
(\%)\end{array}$ & $\begin{array}{c}\text { Butir } \\
\text { Kuning/ } \\
\text { Rusak } \\
(\%)\end{array}$ & $\begin{array}{c}\text { Butir } \\
\text { Mengapur } \\
(\%)\end{array}$ & $\begin{array}{c}\text { Butir } \\
\text { Gabah } \\
(\%)\end{array}$ & $\begin{array}{c}\text { Benda } \\
\text { Asing } \\
(\%)\end{array}$ & $\begin{array}{c}\text { Mutu } \\
\text { Beras }\end{array}$ \\
\hline 1 & Puy & 13,39 & 3,66 & 0,09 & 0,33 & 1,46 & 2 & - & IV \\
2 & Ikang & 11,94 & 11,78 & 0,78 & 0,39 & 0,91 & - & - & III \\
3 & Angga & 12,52 & 3,43 & 1,02 & 0,45 & 2,46 & 2 & - & IV \\
4 & Krayan & 12,51 & 1,58 & 0,41 & 0,59 & 1,33 & - & - & III \\
5 & Keladi & 13,39 & 9,65 & 0,81 & - & 1,44 & 2 & - & IV \\
6 & Merah & 13,25 & 0,72 & 0,07 & 0,89 & 0,61 & 3 & - & V \\
\hline
\end{tabular}

Data Primer : Hasil Penggolongan Mutu Beras Padi Lokal Bulungan

Berdasarkan hasil pengujian kadar air dari beras lokal yang ada menunjukkan beras lokal memiliki persentase kadar air yang bervariasi yaitu $11,94 \%$ - 13,39\%. Beras Ikang memiliki persentase kadar air yang terendah sebesar $11,94 \%$. Sementara beras Puih dan Keladi memiliki persentase kadar air yang tertinggi sebesar 13,39\%. Perbedaan kadar air dari setiap beras lokal yang diuji tidak terlalu menyolok hal ini diduga penanganan pascapanen yang sama saat proses penggilingan dengan melakukan penjemuran gabah terlebih dahulu. Beras lokal yang diuji memenuhi persyaratan mutu beras yaitu kadar airnya $<14 \%$, dimana memenuhi standar mutu I. Jumlah kadar air pada komponen setiap beras sangat berpengaruh terhadap kualitas beras selama dalam penyimpanan. Menurut SNI (2015) beras dengan kadar air dibawah 14\% aman untuk disimpan.

Besarnya hasil persentase jumlah butir patah beras lokal yang diuji menunjukkan persentase butir patah yang bervariasi yaitu 0,72 -11,78 \%. Jumlah beras dengan presentase butir patah terendah adalah beras merah sebesar $0,72 \%$, sedangkan yang tertinggi adalah beras Ikang sebesar 11,78\% .
Persentase jumlah butir patah dari setiap beras lokal yang diuji terlihat adanya perbedaan mutu gabah dari setiap jenis beras lokal. Beras Merah, Puih, dan Krayan tidak terlihat perbedaan yang menyolok terhadap persentase butir patah dimana persentase butir patah beras puih 3,66\% dan beras Krayan 1,58\%. Hal ini diduga tingkat penanganan budidaya, pascapanen dan penggunaan alat pascapanen yang digunakan tidak jauh berbeda. Beras Merah, Puih, Krayan memenuhi mutu beras standar mutu I. Menurut SNI (2015) presentase butir patah mutu I maksimal 5\%. Dibandingkan dengan beras Keladi tingkat perbedaan terhadap persentase beras patah terlihat menyolok dimana persentase butir patah $9,66 \%$. Beras Keladi memenuhi Standar beras mutu II menurut SNI (2015) presentase butir patah mutu II maksimal $10 \%$. Perbedaan ini diduga karena faktor penanganan pascapanen dan varietas. Sementara beras Ikang memiliki persentase butir patah yang tertinggi. Hal ini di duga karena kadar air yang terlalu rendah sehingga mengakibatkan beras mudah patah ketika mengalami proses penggilingan. Pengeringan gabah yang dilakukan sampai 
kadar air $<13 \%$ berpotensi menghasilkan beras patah yang tinggi pada saat dilakukan penggilingan. Beras Ikang berdasarkan persentase butir patah memenuhi standar mutu beras mutu III. Menurut SNI (2015), presentase butir patah mutu III maksimal $20 \%$.

Hasil persentasi butir menir beras lokal yang diuji bervariasi dimana menunjukkan persentase butir menir berkisar antara 0,07 $1,02 \%$. Beras merah menunjukkan jumlah presentase butir menir terendah yaitu $0,07 \%$. Sedangkan beras Angga menunjukkan persentase butir menir tertinggi adalah beras Angga. Beberapa penyebab jumlah persentase butir beras patah /menir disebabkan karena pemanenan gabah belum waktunya sehingga gabah yang masih muda berwarna hijau cenderung mudah patah saat digiling, sebaliknya gabah yang dipanen lewat matang akan mudah rontok di lahan dan mudah pecah saat digiling serta kadar air yang terlalu rendah juga mengakibatkan beras mudah patah ketika mengalami proses penggilingan. Selain itu rangkaian proses selama penggilingan beras juga berpengaruh pada jumlah butir patah. Menurut (Nugraha, 2012), konfigurasi penggilingan akan berpengaruh terhadap kualitas beras yang ditentukan dengan besaran derajat sosoh, persentase beras pecah maupun butir menir yang terjadi. Berdasarkan standar mutu beras menurut SNI (2015), Beras Puy, Ikang, Krayan, Keladi dan beras merah termasuk dalam mutu II dimana menujukkan persentase butir menir $<1 \%$. Menurut SNI (2005) Mutu II dengan presentase butir menir maksimal $1 \%$. Sementara beras Angga menurut standar SNI (2015) masuk dalam kategori mutu III yang jumlah presentase butir menirx > 1\% yaitu $1,02 \%$. Menurut SNI (2015) Mutu III dengan persentase butir menir maksimal $2 \%$.

Jumlah butir kuning/rusak berkisar antara 0,33 $-0,89 \%$. Jumlah beras dengan presentase butir kuning/ terendah adalah beras Puy, sedangkan yang tertinggi adalah beras Merah. Butir kuning/rusak disebabkan oleh proses perubahan warna yang terjadi selama penyimpanan. Berdasarkan presentase butir kuning/rusak semua beras lokal yang diuji termasuk dalam mutu II dengan presentase butir kuning/rusak maksimal $1 \%$.

Jumlah butir mengapur berkisar antara 0,61-2,46 \%. Jumlah beras dengan presentase butir mengapur terendah adalah beras merah, sedangkan yang tertinggi adalah beras Angga. Butir mengapur berasal dari gabah yang masih muda atau pertumbuhannya kurang sempurna atau faktor genetik sehingga menyebabkan beras lebih rapuh dan mudah hancur bila digiling dan kurang disukai oleh konsumen. Berdasarkan presentase butir mengapurnya semua beras tersebut termasuk dalam mutu II, III dan IV. Beras Ikang dan beras merah termasuk mutu II dengan presentase butir kapur $<1 \%$. Beras Puih, Krayan dan Keladi termasuk mutu III dengan presentase butir kapur $<2 \%$. Beras Angga termasuk mutu IV dengan presentase butir kapur $<3 \%$.

Jumlah butir gabah dari beras varietas lokal di Bulungan berkisar antara 2-3\%. Berdasarkan presentase butir gabah semua beras tersebut termasuk dalam golongan IV dan V menurut SNI dengan presentase butir gabah maksimal 3\%. Berbagai faktor yang menyebabkan butir gabah meliputi keadaan lingkungan, panen hingga penanganan lepas panen di samping faktor genetik (Haryadi, 2006).

Jumlah butir asing dari beras varietas lokal berdasarkan presentase butir asing semua beras tersebut termasuk dalam golongan I menurut SNI dengan presentase butir gabah maksimal $0 \%$.

Penggolongan mutu beras lokal berdasarkan persyaratan yang sesuai dengan SNI 6128: 2015, menunjukkan bahwa beras lokal yang ada di Bulungan memenuhi persyaratan standar mutu beras III, IV dan V. Beras Ikang dan Krayan yang dibudidayakakan secara organik dengan sistem pertanian sawah tradisional oleh masyarakat dataran tinggi memenuhi mutu III. Beras Puy, Angga, dan Keladi memenuhi mutu beras IV. Sedangkan beras merah memenuhi mutu beras V. Hal ini menunjukkan bahwa mutu beras lokal masih 
tergolong rendah dan perlu dilakukan penanganan pascapanen yang lebih baik untuk meningkatkan mutu fisik beras sehingga beras yang dihasilkan mampu untuk bersaing dalam pasar.
Sifat kimia dari setiap kandungan beras yang dihasilkan sangat berpengaruh besar terhadap kualitas mutu tanak nasi yang dihasilkan. Karakteristik Sifat kimia beras lokal Bulungan dapat dilihat pada tabel 3.

\subsection{Sifat Kimia Beras}

Tabel 3. Sifat kimia beras varietas padi lokal di Bulungan

\begin{tabular}{|c|c|c|c|c|c|c|c|c|}
\hline No & Varietas & $\begin{array}{c}\text { Protein } \\
(\%)\end{array}$ & $\begin{array}{c}\text { Lemak } \\
(\%)\end{array}$ & $\begin{array}{c}\text { Serat } \\
(\%)\end{array}$ & $\begin{array}{l}\text { Abu } \\
(\%)\end{array}$ & $\begin{array}{c}\text { BETN } \\
(\%)\end{array}$ & $\begin{array}{c}\text { Amilosa } \\
(\%)\end{array}$ & $\begin{array}{c}\text { Kriteria } \\
\text { Kandungan } \\
\text { Amilosa } \\
\text { Beras }\end{array}$ \\
\hline 1 & Puy & 7,37 & 1,02 & 0,43 & 0,40 & 77,39 & 16,6 & Rendah \\
\hline 2 & Ikang & 8,55 & 0,92 & 0,10 & 0,42 & 78,07 & 8,21 & $\begin{array}{l}\text { Sangat } \\
\text { Rendah }\end{array}$ \\
\hline 3 & Angga & 8,66 & 1,27 & 0,58 & 0,57 & 76,40 & 10,25 & Rendah \\
\hline 4 & Krayan & 7,40 & 1,51 & 0,03 & 0,41 & 78,14 & 11,55 & Rendah \\
\hline 5 & Keladi & 10,10 & 1,91 & 0,30 & 0,91 & 73,32 & 4,59 & $\begin{array}{l}\text { Sangat } \\
\text { Rendah }\end{array}$ \\
\hline 6 & Merah & 8,70 & 1,27 & 0,58 & 0,76 & 74,14 & 15,2 & Rendah \\
\hline
\end{tabular}

Data Primer : Hasil Pengujian Sifat Kimia Beras Lokal Bulungan

\subsubsection{Kadar Protein}

Protein merupakan salah satu zat gizi yang sangat diperlukan oleh makhluk hidup yang sebagian besar terdiri atas unsur nitrogen. Kadar protein dari setiap beras yang diuji berada pada kisaran 7,37- 10,10\%. Hal ini menunjukkan bahwa kadar protein beras lokal Bulungan menghasilkan kandungan protein yang sesuai dengan standar nilai gizi beras yaitu sebesar 7\%. Nilai protein tertinggi beras lokal dimiliki oleh varietas beras Keladi $(10,10 \%)$. Sedangkan nilai kadar protein terendah dimiliki oleh vareitas beras Puy $(7,37 \%)$. Perbedaan kadar protein yang dihasilkan dari setiap beras lokal yang diuji tidak memperlihatkan perbedaan yang menyolok. Kadar protein pada beras giling sangat dipengaruhi oleh derajat sosoh dan kondisi tanah tempat beras yang ditanam. Beras yang tumbuh pada tanah yang kaya akan unsur $\mathrm{N}$ akan cenderung memiliki kadar protein yang tinggi (Juliano, 1972).

Protein beras merupakan salah satu unsur gizi setelah karbohidrat. Sumbangan gizi protein beras bagi tubuh manusia yang mengkomsumsinya cukup tinggi.
Disamping itu kandungan protein dalam beras menurut Ishima et.al (1984) dalam Setyono dan Wibowo (2008) mempengaruhi tekstur nasi yang dihasilkan. Beras dengan kadar protein tinggi biasanya menghasilkan nasi yang kurang lunak (cenderung keras). Protein beras bersifat menghambat penyerapan air dan pengembangan granula pati ketika beras ditanak, sehingga membatasi kemampuan pati membentuk gelatinisasi secara optimal. Menurut Setyono dan Wibowo (2008), faktor genetik, teknologi budidaya, pemupukan, dan agroekosistem wilayah pertanaman padi diketahui banyak mempengaruhi kuantitas kadar protein.

\subsubsection{Kadar Lemak}

Lemak pada beras mengandung banyak asam lemak tidak jenuh dan memiliki peranan penting dalam citarasa suatu bahan pangan, sehingga ketika mengalami oksidasi lemak mengakibatkan perubahan menjadi apek sehingga akan terjadi penyimpangan bau dan rasa. Kandungan lemak tertinggi biji beras terdapat dalam lembaga dan lapisan 
aleuron yang tekumpul dalam butiran lemak. Kadar lemak beras lokal berada di kisaran 0,92- $1,91 \%$. Kadar lemak tertinggi dimiliki oleh varietas beras Keladi (1,91\%) dan yang terendah varietas beras Ikang $(0,92 \%)$. Kadar lemak beras lokal Bulungan tidak sesuai dengan standar nilai gizi yang sesuai dengan Anonim (2009) yaitu sebesar 0,66\%. Kandungan lemak beras lokal Bulungan dimungkinkan dipengaruhi oleh faktor varietas, derajat kematangan biji, kondisi pertanaman, penyimpanan dan metode ekstraksi lemak. Perbedaan kadar lemak beras lokal tidak menunjukkan perbedaan yang menyolok hal ini disebabkan karena adanya proses budidaya, penanganan pascapanen dan proses penggilingan yang dilakukan tidak jauh berbeda dari setiap petani padi. Menurut Ryan (2011), kulit bekatul beras hilang selama penggilingan dan akan semakin hilang apabila tingkat polishing beras meningkat.

\subsubsection{Kadar Serat}

Serat pangan adalah salah satu jenis komponen bahan pangan yang saat ini seringkali digunakan sebagai komponen utama dalam produk - produk pangan khusus bersama dengan zat bioaktif (Ryan 2011). Serat pada bahan pangan terdiri dari serat pangan larut air dan serat pangan tidak larut air, namun keduanya tetap memiliki fungsi kesehatan pada tubuh manusia (Ausman et.al 2005). Kadar serat kasar beras lokal berada dalam kisaran 0,03-0,58 \%. Serat Kasar tertinggi dimiliki oleh varietas beras merah $(0,03 \%)$ dan yang terendah varietas beras Krayan $(0,58 \%)$. Serat kasar yang dihasilkan tergolong cukup rendah hal ini dapat terjadi karena serat pada beras terpusat di bekatul beras, sehingga perlakuan penyosohan sangat berpengaruh terhadap jumlah total serat pangan yang tersedia (Ryan 2011; Fujino 1978; Houston dan Kohler 1970). Menurut Rimbawan \& Siagian (2004), bahwa keberadaan serat pangan memberikan pengaruh pada kadar gula darah. Serat terlarut dapat menurunkan respon glikemik pangan secara nyata, sedangkan serat kasar mempertebal kerapatan atau ketebalan campuran makanan dalam saluran pencernaan. Hal ini memperlambat laju makanan pada saluran pencernaan dan menghambat pergerakan enzim. Dengan demikian, proses pencernaan menjadi lambat, sehingga respon glukosa darah lebih rendah.

\section{3.5.Kadar Abu.}

Abu adalah residu anorganik yang didapatkan setelah proses penghilangan bahan-bahan organik yang terkandung dalam suatu bahan (Sudarmadji et .al,1996). Kadar abu ditentukan berdasarkan kehilangan bobot yang terjadi setelah sampel mengalami proses pembakaran pada suhu yang sangat tinggi $\left(500-600{ }^{\circ} \mathrm{C}\right)$. Kadar abu secara kasar dapat mencerminkan kadar mineral yang terkandung dalam beras. Kadar Abu beras lokal berada di kisaran 0,40\%$0,91 \%$. Kadar abu tertinggi dimiliki oleh beras Keladi $(0,91 \%)$ dan yang terendah dimiliki oleh beras Puy $(0,40 \%)$. Kadar abu pada beras dipengaruhi oleh derajat penyosohan dan kandungan unsur hara dalam tanah.

Menurut Juliano (1972), distribusi mineral pada beras yang sudah disosoh adalah sekitar $28 \%$ dari total mineral yang terkandung pada beras pecah kulit. Kandungan mineral terbesar ditemukan pada bagian dedak yaitu sebesar $51 \%$ dari total mineral yang terkandung dalam beras pecah kulit. Proses penyosohan adalah proses yang paling bertanggung jawab terhadap rendahnya kandungan mineral pada beras giling yang dikonsumsi sehari-hari. Kandungan mineral pada beras sebagian besar ditemukan pada bagian dedak dan embrio yang hilang pada saat proses penyosohan (Rosniyana et. al , 2006).

\subsubsection{Karbohidrat}

Karbohidrat adalah zat gizi yang dapat ditemui dalam jumlah terbesar pada beras. Karbohidrat dalam serealia termasuk beras sebagian besar terdapat dalam bentuk pati. kadar karbohidrat beras lokal berada di kisaran 73, 32\%-78,14\%. Kadar karbohidrat tertinggi dimiliki oleh varetas beras Krayan 
$(78,14 \%)$ dan terendah beras Keladi $(73,32 \%)$. Kandungan karbohidrat beras lokal Bulungan tergolong rendah dibandingkan dengan standar gizi beras yang sesuai dengan Anonim (2009) dan Larasati (2013), yaitu sebesar 79\% .

\subsubsection{Kadar Amilosa}

Kadar amilosa adalah salah satu kriteria penting dalam menentukan sifat pati dalam beras yang sangat berpengaruh terhadap rasa nasi yang dihasilkan. Berdasarkan kadar amilosanya, beras lokal Bulungan yang diuji diklasifikasikan menjadi beras beramilosa sangat rendah $(<10 \%)$ dan beramilosa rendah $(10-20 \%)$. Beras Puy $(16,6 \%)$, beras Angga (10,25\%), beras Krayan (11,5\%), dan beras merah $(15,2 \%)$ tergolong beras dengan kadar amilosa rendah. Sedangkan beras Ikang $(8,21 \%)$ dan beras keladi $(4,59 \%)$ tergolong beras dengan kadar amilosa sangat rendah. Menurut Damardjati, (1995), bahwa beras yang berkadar amilosa rendah bila dimasak menghasilkan nasi lengket, mengkilap, tidak mengembang, dan tetap menggumpal setelah dingin. Beras yang berkadar amilosa tinggi bila dimasak nasinya tidak lengket, dapat mengembang, dan menjadi keras jika sudah dingin, sedangkan beras beramilosa sedang umumnya mempunyai tekstur nasi pulen.

Kandungan amilosa mempengaruhi tekstur nasi. Beras dengan kandungan amilosa tinggi akan menghasilkan nasi dengan volume pengembangan yang tinggi, tekstur yang keras dan kering. Beras dengan kandungan amilosa rendah akan menghasilkan nasi yang lembut dan lengket. Semakin tinggi kadar amilosa beras semakin pera tekstur nasi dan semakin rendah amilosa beras semakin pulen tekstur nasi. Menurut Ramesh et al. (1999), Tekstur nasi ditentukan oleh interaksi komponen struktur pati seperti banyaknya rantai panjang, amilosa bebas, dan amilosa terikat dengan amilopektin. Karena itu, beras dengan kandungan amilosa yang sama tidak berarti memiliki tekstur yang persis sama, bergantung pada struktur pati beras tersebut.
Kandungan amilosa merupakan bagian konstituen dari pati beras, dengan satuan struktur-anhidroglukosa yang dihubungkan oleh $\alpha-1,4$ ikatan glikosidik, dan ikatan hidrogen pada intramolekul menyebabkan rantai spiral membentuk struktur sekrup berongga atau dikenal dengan double helix. Kandungan amilosa memiliki hubungan dekat dengan suhu gelatinisasi pati. Beras dengan kandungan amilosa tinggi, suhu gelatinisasi tinggi, dan nilai alkali rendah akan menyebabkan tekstur beras kering dan lembek serta viskositas rendah, namun tidak mudah rusak dalam proses tanak. Sebaliknya, beras dengan amilosa rendah, suhu gelatinisasi rendah, dan nilai alkali tinggi menyebabkan viskositas tinggi dan mudah rusak. Kandungan amilosa juga mempengaruhi penyerapan air dan tingkat ekspansi dalam proses tanak. Umumnya, beras dengan kandungan amilosa rendah dianggap lezat. Hal ini terkait dengan struktur pecular, karakter anti-bengkak (anti-swelling), daya rentang yang baik, dan karakter gel amilosa yang berdekatan (Qin $e t$ al. 2014).

Perbedaan kadar amilosa beras lokal Bulungan dimungkinkan dipengaruhi oleh faktor jenis varietas, lokasi penanaman, kadar $\mathrm{N}$ dalam tanah, waktu panen dan penyimpanan gabah serta pengaruh perubahan pascapanen beras selama penyimpanan. Penelitian oleh Juliano (1979) menunjukkan bahwa beras dengan varietas yang sama namun ditanam pada daerah yang memiliki perbedaan kandungan nitrogen dalam tanah dan suhu udara lokasi penanaman yang berbeda akan menghasilkan beras dengan kandungan amilosa yang berbeda. Penelitian tersebut menunjukkan bahwa kadar amilosa pada beras berbanding terbalik dengan suhu udara lokasi penanaman dan kadar $\mathrm{N}$ dalam tanah. Disamping itu menurut Chrastil (1990), perubahan komposisi kimia beras selama penyimpanan disebabkan oleh kegiatan enzim dalam biji yang masih aktif setelah padi dipanen. Perubahan pascapanen padi mempengaruhi sifat-sifat kimiawi, fisikokimiawi, dan sifat fungsional beras. 
Kecepatan dan besarnya perubahan sifatsifat gabah terutama disebabkan oleh suhu penyimpanan dan kadar air. Makin tinggi suhu dan kadar air, makin besar perubahan yang terjadi. Kadar amilosa meningkat selama penyimpanan, disebabkan suhu yang semakin naik (selalu berubah-ubah sesuai dengan suhu ruang) dan lamanya penyimpanan.

Kandungan amilosa beras juga sangat berpengaruh terhadap tingkat glisemik beras lokal Bulungan. Beras beramilosa tinggi dilaporkan tidak menaikkan kadar glukosa darah secara drastis dibandingkan dengan beras beramilosa sedang maupun rendah (Miller et. al, 1992). Hal ini juga didukung oleh Rusilanti (2008), bahwa pangan yang memiliki kadar amilosa dan amilopektin berbeda menunjukkan kadar glukosa darah dan pengaruh insulin lebih rendah setelah mengkonsumsi pangan berkadar amilosa tinggi daripada pangan berkadar amilopektin tinggi. Makanan yang tinggi kandungan amilopektin dan rendah amilosa pada zat tepungnya memiliki IG tinggi, karena molekul amilopektin lebih besar, mudah terbuka, mudah tergelatinisasi, dan mudah dicerna. Makanan dengan rasio perbandingan amilosa lebih tinggi dari amilopektin memiliki indeks glikemik rendah karena lebih sulit tergelatinisasi dan dicerna.

\section{KESIMPULAN}

Penelitian yang dilakukan pada beras lokal di beberapa wilayah Bulungan menunjukkan karakteristik fisik, kimia dan standar mutu yang bervariasi.

1. Sifat fisik beras padi lokal menunjukkan karakteristik dengan memiliki derajat putih yang bervariasi antara 58,8 - 54,6\%. Nilai kebeningan berada pada kisaran $1.70-2.57 \%$. Bentuk dan ukuran beras bervariasi yaitu memiliki ukuran panjang dan ukuran sedang sementara bentuk beras yang dihasilkan yaitu bentuk beras yang ramping dan medium.

2. Sifat kimia beras lokal menujukkan karakteristik dengan kandungan peroksimat yang bervariasi yaitu memiliki kandungan protein pada kisaran 7,37- 10,10\%. Kadar lemak pada kisaran $0,92-1,91 \%$. Kadar serat kasar pada kisaran 0,03-0,58 \%. Kadar abu pada kisaran 0,41-0,91\%. Kadar karbohidrat pada kisaran 73,32 - 78,07\%. Kandungan amilosa rendah $(<20 \%)$. Kandungan beras lokal yang diuji memiliki kadar amilosa berkisar antara 3,61-16,6\%.

3. Penggolongan mutu beras lokal berdasarkan persyaratan yang sesuai dengan SNI 6128: 2015, menunjukkan bahwa beras lokal yang ada di Bulungan memenuhi persyaratan standar mutu beras III, IV dan V. Beras Ikang dan Krayan yang dibudidayakakan secara organik dengan sistem pertanian sawah tradisional oleh masyarakat dataran tinggi memenuhi mutu III. Beras Puy, Angga, dan Keladi memenuhi mutu beras IV. Sedangkan beras merah memenuhi mutu beras $\mathrm{V}$.

\section{UCAPAN TERIMA KASIH}

Ucapan terima Kasih kepada Direktorat Jederal Penguatan Riset dan Pengembangan Kementerian Riset, Teknologi, dan Pendidikan Tinggi yang telah mendanai kegiatan penelitian ini, Lembaga Penelitian dan Pengabdian Masyarakat Unikaltar yang telah banyak membantu dan mendorong kegiatan terselenggaranya penelitian ini, Rektor Universitas Kaltara, Prof. Abdul Jabarsyah, M.Sc, Wakil Rektor I, II dan III, Dekan Fakultas Pertanian Unikaltar, rekan sejawat di Lingkungan Fakultas Pertanian unikaltar atas dukungan dan supporting tinggi. Prof. DR. Enos Tangke Arung. P.hd selaku revierw yang telah banyak memberikan masukan dan bimbingan bagi peneliti.

\section{DAFTAR PUSTAKA}

\section{Askanovi D. 2011. Kajian Resistensi Beras Pecah Kulit Dan Beras Sosoh Dari Lima Varietas Padi Unggul Terhadap}


Serangan Hama Beras Sitophilus oryzae (L.). Skripsi. Bogor : FATETA IPB.

Akhbar, M. A. 2015. Analisis Sifat Fisikokimia dan Sifat Fungsional Beras (Oryza sativa) Varietas Beras Hitam dan Beras Merah asal Cianjur, Solok, dan Tangerang. Skripsi. Departemen Ilmu dan Teknologi Pangan. Fakultas Teknologi Pertanian. Institut Pertanian Bogor, Bogor.

Ausman LM, Rong N, Nicolosi RJ. Hypocholesterolemic effect of physically refined rice bran oil: studies of cholesterol metabolism and early atherosclerosis in hypercholesterolemic hamsters. J Nutr Biochem. 2005 (16):521-529.

Anonim, 2009. Nutrisi Beras. htt p://az aima.tri pod .com/ka ndungan_gizi/id2 .html.

Badan Standarisasi Nasional (BSN). 2015. Standar mutu dan cara uji beras giling. Standar Nasional Indonesia (SNI) No. 01-6128-2015. Jakarta.

Badan Standardisasi Nasional. (2008). SNI 6128:2008 Beras. Jakarta: BSN

Balitbangtan, 2011. Pedoman Umum Adaptasi Perubahan Iklim Sektor Pertanian. Badan Penelitian dan Pengembangan Pertanian. Kementerian Pertanian.

Balai Pengkajian Teknologi Pertanian (BPTP) Yogyakarta. 2006. Laporan Tahunan Balai Pengkajian Teknologi Pertanian Yogyakarta. Badan Penelitian dan Pengembangan Pertanian. Jakarta.

Bergman, R.N., Kim, S.P., Catalano, K.J., Hsu, I.R., Chiu, J.D., Kabir, M., et al. 2006. Why Visceral Fat is Bad: Mechanisms of the Metabolic Syndrome. Obesity, (14):16-19.
Dianti, R. W. 2010. Kajian karakteristik fisikokimia dan sensori beras organik dan IR64, pecah kulit dan giling selama penyimpanan. Skripsi. Universitas Sebelas Maret. Surakarta.

Damardjati, D. S. 1995. Karakteristik Sifat Standarisasi Mutu Beras sebagai Landasan Pengembangan Agribisnis dan Agroindustri Padi di Indonesia. Balai Penelitian Teknologi Pangan. Bogor.

Haryadi. 2006. Teknologi Pengolahan Beras. Penerbit UGM Press. Yogyakarta.

IRRI, 2002. Rice grain quality evaluation procedures. Methods currently in use the PBGB (Plant Breeding, Genetic and Biochemistry) grain quality laboratory. International Rice Research Institute, Los Banos, Philippines.

Irawan B, Purbayanti K. 2008. Karakterisasi dan kekerabatan kultivar padi lokal di desa Rancakalong Kecamatan Rancakalong Kabupaten Sumedang. Seminar Nasional PTTI, CibinongBogor, 21-23 Oktober 2008.

Lambert, D.M. dan Cooper, M.C. (2000). Issues in Supply Chain Management. Journal Industrial Marketing Management. 29, 65-83.

Larasati, A. S. 2013. Glikemik Snack Bar Beras Warna sebagai Makanan Selingan Penderita Nefropati Diabetik, Skripsi S1, Universitas Diponegoro.

Nugraha S. 2012. Inovasi Teknologi Pascapanen Untuk Mengurangi Susut Hasil Dan Mempertahankan Mutu Gabah/Beras di Tingkat Petani. Balai Besar Penelitian dan Pengembangan Pascapanen Pertanian. Buletin Teknologi Pascapanen Pertanian vol 8 (1) ; p. 48-61. 
Muchtadi, Tien R. 1992. Ilmu Pengetahuan Bahan Pangan. IPB Press. Bogor.

Rosniyana A, Rukunudin IH, Shariffah Norin SA. Effects of milling degree on the chemical composition, physicochemical properties and cooking characteristics of brown rice. J Trop Agric and Fd Sc. 2006 (1): 37- 44.

Ryan EP. Bioactive food components and health properties of rice bran. Javma. 2011 (238): 593- 600. Vet Med Today: Timely Topics in Nutrition.

Priyanto. 2012. Beras Ketan Dan Sifat Fisika-Kimia.

http://www.alatcetakrengginang.com/20 12/02/beras-ketan-sifat-fisika-kimianya.

Setyono, A., Bram, K., Jumali dan Prihadi W. (2008), "Evaluasi Mutu Beras di Beberapa Wilayah Sentra Produksi Padi", dalam Prosiding Seminar Nasional Padi 2008, Eds: Setyono dkk, Balai Besar Penelitian Tanaman Padi, Subang.
Susilowati, E. 2010. Kadar amilosa pada nasi yang disubtitusi denga ubi jalar (Ipomoea batatas L.) sebagai bahan makanan pokok. Skripsi. Universitas Sebelas Maret. Surakarta.

Singh, U.S., R. Rohilla, P.C., Srivastava, N.S., Singh, R.K., (2003). Environmental factors affecting aroma and other quality traits. In A Treatise on the Scented Rice of India. Ludhiana: Kalyani Publishers, pp. 143-164.

Sudarmadji. S., Haryono, B., Suhardi. 1996. Makanan dan Pertanian Analisa Bahan. Liberty Yogyakarta. Yogyakarta.

Juliano, B.O. 1979. Amylose Analysis in Rice. Di dalam : Proceedings of the Workshop on Chemical Aspect of Rice Grain Quality. IRRI, Los Banos, pp 252259.

Yusof, B.N.M., R.A. Talib, and N.A. Karim. 2005. Glycemic index of eight types of commercial rice. Mal. J. Nutr. 11(2):151-163. 